\title{
KONDYCJA FINANSOWA PRYWATNYCH WYDAWCÓW TYGODNIKÓW LOKALNYCH
}

\author{
Abstract \\ FINANCIAL CONDITION OF PRIVATE PUBLISHERS OF LOCAL WEEKLY \\ NEWSPAPERS
}

The condition for the existence of independent local press is its economic self-sufficiency. An analysis of the financial statements of private local weekly publishers shows that their financial condition has deteriorated significantly in recent years. This was mainly due to the decline in print press readership and the outflow of advertisers to the Internet. Revenues from issue sales and advertising revenue in 2018 decreased by an average of $1 / 3$ compared to 2010 . The reduction in publishing costs slightly improved the financial results of the owners of local weeklies. Their profits decreased on average by $150 \%$, which for most meant incurring losses on operations. The deteriorating financial condition of publishers threatens a reduction of the quality of the local press, recduction of the number of titles or further concentration of ownership in this media segment.

Key words: local press, local weeklies, financial results of publishers

\section{Wprowadzenie}

Prasa lokalna stanowi ważny element systemu demokratycznego i istotny czynnik rozwoju społeczeństwa obywatelskiego. Warunkiem jej istnienia jest samowystarczalność ekonomiczna gwarantująca niezależność i swobodę w prezentowaniu treści. Dochodowość działalności wydawniczej sprzyja ponadto rozwojowi prasy lokalnej, w tym wprowadzaniu nowych technologii, doskonaleniu kwalifikacji dziennikarzy, skutecznej konkurencji rynkowej.

Przedmiotem niniejszej analizy jest kondycja finansowa prywatnych wydawców prasy lokalnej. Za takich uznaje się samodzielnych, niezależnych wydawców 
tygodników lokalnych. Użyte określenia nie mają charakteru oceny. Służą jedynie podkreśleniu, że nie są oni częścią dużych koncernów prasowych, nie otrzymują stałych dotacji z jakichkolwiek instytucji, a głównym źródłem finansowania ich działalności wydawniczej jest sprzedaż egzemplarzowa i reklamy.

Ocena kondycji finansowej właścicieli lokalnych tytułów prasowych została przeprowadzona na podstawie sprawozdań finansowych za lata 2010-2018 składane do Krajowego Rejestru Sądowego. Dotychczas nie wykorzystywano tego typu dokumentów do analiz mediów lokalnych ze względu na kosztowny pod względem organizacyjnym i finansowym proces ich pozyskiwania.

\section{Stan badań}

Prasa lokalna jest najmniej zbadanym i najtrudniejszym w analizie segmentem rynku medialnego. Istnieje kilka publikacji poruszających teoretyczne aspekty funkcjonowania mediów lokalnych oraz charakteryzujących ich pozycję w systemie społecznym i politycznym ${ }^{1}$. Nie prowadzi się jednak na poziomie krajowym empirycznych badań nad prasą lokalną, choć nie brakuje wnikliwych analiz różnych rodzajów mediów lokalnych ${ }^{2} \mathrm{i}$ ich funkcjonowania $\mathrm{w}$ poszczególnych regionach ${ }^{3}$. Nieliczna część tych opracowań dotyczy ekonomicznych aspektów funkcjonowania mediów lokalnych. Badaczy interesują na ogół takie zagadnienia, jak koncentracja własności na rynku dzienników regionalnych i konkurencja ze strony

1 Por. m.in.: S. Michalczyk, Media lokalne w systemie komunikowania. Wspólczesne tendencje i uwarunkowania rozwojowe, Wydawnictwo Uniwersytetu Śląskiego, Katowice 2000; M. Gierula, Polska prasa lokalna 1989-2000. Typologia i społeczne funkcjonowanie, Wydawnictwo Uniwersytetu Śląskiego, Katowice 2005; M. Jachimowski, Regiony periodycznej komunikacji medialnej. Studium prasoznawczo-politologiczne o demokratyzacji komunikacji medialnej, Wydawnictwo Uniwersytetu Śląskiego, Katowice 2006; R. Kowalczyk, Media lokalne w Polsce, t. 1-3, Wydawnictwo „Contact", Poznań 2008.

2 Zainteresowaniem badaczy cieszy się np. prasa samorządowa (zob. P. Szostok, R. Rajczyk, Komunikowanie lokalne w Polsce. O instrumentach polityki komunikacyjnej samorządów, Gnome Wydawnictwa Naukowe i Artystyczne, Katowice 2013; J. Kępa-Mętrak, Prasa samorządowa w polskim systemie medialnym, Wydawnictwo Uniwersytetu Jana Kochanowskiego; Kieleckie Towarzystwo Naukowe, Kielce 2015), dzienniki regionalne (zob. Dzienniki regionalne w Polsce, red. nauk. P. Kuca, W. Furman, K. Wolny-Zmorzyński, Wydawnictwo Uniwersytetu Rzeszowskiego, Rzeszów 2014) czy regionalne media publiczne (zob. np. Radio regionalne $w$ Polsce, red. nauk. P. Kuca, W. Furman, K. Wolny-Zmorzyński, Wydawnictwo Uniwersytetu Rzeszowskiego, Rzeszów 2016; Publiczna telewizja regionalna $w$ Polsce, red. nauk. P. Kuca, W. Furman, K. Wolny-Zmorzyński, Wydawnictwo Uniwersytetu Rzeszowskiego, Rzeszów 2018).

3 Por. m.in.: A. Szynol, Prasa codzienna na Dolnym Śląsku 1989-2003, Wydawnictwo Naukowe Dolnośląskiej Szkoły Wyższej Edukacji TWP, Wrocław 2004; L. Pokrzycka, Prasa ogólnoinformacyjna w regionie lubelskim po 1989 r., Wydawnictwo Uniwersytetu Marii Curie-Skłodowskiej, Lublin 2009; Media lokalne w Szczecinie. Raport z badań mediów lokalnych w Szczecinie w 2010 roku, red. J. Kania, R. Cieślak, Wydawnictwo Naukowe Uniwersytetu Szczecińskiego, Szczecin 2011. 
prasy samorządowej ${ }^{4}$. Przyczyną swoistej luki badawczej na temat potencjału ekonomicznego prasy lokalnej jest ograniczony dostęp do danych finansowych wydawców oraz brak informacji na temat wielkości sprzedaży i wpływów reklamowych w tym segmencie prasy.

\section{Diagnoza sytuacji}

Trudno określić dokładną liczbę wydawców prasy lokalnej w Polsce. Posiłkując się klasyfikacją Biblioteki Narodowej, która prowadzi wykaz podmiotów wydawniczych na podstawie zapisów ustawy o obowiązkowych egzemplarzach bibliotecznych ${ }^{5}$, można wśród nich wyróżnić wydawców profesjonalnych (rozmaite instytucje wydawnicze, spółki, przedsiębiorstwa prasowe, spółdzielnie dziennikarskie itp.) oraz nieprofesjonalnych, dla których wydawanie prasy nie jest podstawowym rodzajem działalności (organizacje społeczne i polityczne, towarzystwa naukowe, samorząd terytorialny, instytucje kulturalne itp.).

Równie trudne jest określenie liczby tygodników lokalnych. Dużą ich część stanowią pisma bezpłatne o charakterze ogłoszeniowym. Płatne tygodniki informacyjne to domena Grupy Polska Press, która wydaje ich blisko 150, oraz mniejszych wydawców edytujących od jednego do kilku tytułów. Tylko na podstawie tytułów zgłoszonych do Porozumienia Reklamowego Tygodnik Lokalny ich liczbę można szacować na 150-2006 . Poza tą grupą pozostają jeszcze tytuły nigdzie niezrzeszone, niepoddające się kontroli nakładu i badaniom czytelnictwa. Jeżeli przyjąć, że w każdym powiecie w Polsce wydawany jest przynajmniej jeden płatny tygodnik informacyjny, ich liczba może oscylować w granicach 400. Choć w niektórych regionach oferta wydawnicza wydaje się większa, to składają się na nią tygodniki obejmujące swym zasięgiem kilka miejscowości, bezpłatne pisma ogłoszeniowe, periodyki (najczęściej miesięczniki) wydawane przez samorząd oraz tygodniki będące dodatkiem do dzienników regionalnych.

4 Zob. L. Szot, Koncentracja kapitału na polskim rynku prasowym. Studium przypadku, „Studia Medioznawcze” 2017, nr 2, s. 111-123; A. Szynol, Czy Polsce wciąż potrzebna jest regionalna prasa codzienna?, „Zeszyty Prasoznawcze” 2017, nr 3, s. 468-493; E. Jaruga-Wosik, Strukturalne i jakościowe przemiany $w$ mediach lokalnych, „Polityczne Studia Środkowoeuropejskie” 2016, nr 4, s. $125-144$.

5 Ustawa z 7 listopada 1996 r. o obowiązkowych egzemplarzach bibliotecznych, Dz.U. 1996, nr 152, poz. 722 .

6 Porozumienie Reklamowe Tygodnik Lokalny to inicjatywa Stowarzyszenia Gazet Lokalnych, by opierając się na badaniach czytelnictwa prasy lokalnej, prowadzić wspólną politykę reklamową i pozyskiwać reklamy z rynku ogólnopolskiego. Biuro Reklam Gazet Lokalnych (BRGL) podawało, że w 2016 r. udział w porozumieniu brało 200 tygodników lokalnych. W 2019 r. w ofercie BRGL były 153 tytuły. 


\section{Tygodniki lokalne na rynku czytelniczym}

Według badań prowadzonych przez Bibliotekę Narodową wskaźniki czytelnictwa prasy w Polsce systematycznie maleją. W latach 2012-2017 odsetek nieczytających zwiększył się o 13 punktów procentowych (z 41 do 54\%). Prawie połowa respondentów (48\%) przyznała w 2017 roku, że nie czyta prasy papierowej ${ }^{7}$.

Prasa, jako źródło informacji i rozrywki, straciła swoją pozycję najpierw na skutek konkurencji ze strony mediów elektronicznych, a następnie internetu. Dostarczały one odbiorcom pożądane treści szybciej, w bardziej przystępnej formie, a co najważniejsze - taniej. Przyczyniły się też do - wydaje się nieodwracalnych zmian kulturowych i sposobów konsumpcji treści.

$\mathrm{Na}$ spadek czytelnictwa prasy drukowanej najwyraźniej wskazują dane dotyczące sprzedaży egzemplarzowej prasy oraz wskaźniki czytelnictwa poszczególnych tytułów prasowych. Negatywne trendy występujące na rynku prasy ogólnopolskiej dotyczą również tygodników lokalnych. Rozpowszechnianie płatne kontrolowanych przez Związek Kontroli Dystrybucji Prasy (ZKDP) tytułów spadło od 2010 do 2017 roku średnio o 1/3 (por. tabela 1).

Tabela 1. Rozpowszechnianie wybranych tygodników lokalnych w 2010 i 2017 r. (w egz., zmiana $w \%)$

\begin{tabular}{|l|r|r|r|}
\hline & \multicolumn{1}{|c|}{$\mathbf{2 0 1 0}$} & \multicolumn{1}{c|}{$\mathbf{2 0 1 7}$} & Zmiana 2017 do 2010 \\
\hline „Tygodnik Zamojski” & 26995 & 19644 & $\mathbf{- 2 7 , 2 3 \%}$ \\
\hline „Tygodnik Siedlecki - Magazyn” & 26178 & 14548 & $\mathbf{- 4 4 , 4 3 \%}$ \\
\hline „Tygodnik Ostrołęcki” & 23957 & 9772 & $\mathbf{- 5 9 , 2 1 \%}$ \\
\hline „Tygodnik Podhalański” & 17535 & 12196 & $\mathbf{- 3 0 , 4 5 \%}$ \\
\hline „TEMI Galicyjski Tygodnik Informacyjny” & 16830 & 10655 & $\mathbf{- 3 6 , 6 9 \%}$ \\
\hline „Tygodnik Ciechanowski” & 14724 & 9852 & $\mathbf{- 3 3 , 0 9 \%}$ \\
\hline „Życie Podkarpackie” & 12058 & 8808 & $\mathbf{- 2 6 , 9 5 \%}$ \\
\hline „Przełom - Tygodnik Ziemi Chrzanowskiej” & 9964 & 6740 & $\mathbf{- 3 2 , 3 6 \%}$ \\
\hline „Nowiny Jeleniogórskie” & 9783 & 4425 & $\mathbf{- 5 4 , 7 7 \%}$ \\
\hline „Nowy Łowiczanin” & 8362 & 6792 & $\mathbf{- 1 8 , 7 8 \%}$ \\
\hline „Obserwator Lokalny” & 8259 & 8019 & $\mathbf{- 2 , 9 1 \%}$ \\
\hline „Życie Bytomskie” & 8182 & 4280 & $\mathbf{- 4 7 , 6 9 \%}$ \\
\hline „Gwarek” & 7664 & 5750 & $\mathbf{- 2 4 , 9 7 \%}$ \\
\hline „Czas Chojnic” & 6260 & 5924 & $\mathbf{- 5 , 3 7 \%}$ \\
\hline „Tygodnik Tucholski” & 6159 & 5294 & $\mathbf{- 1 4 , 0 4 \%}$ \\
\hline „Strzelec Opolski” & 5916 & 5313 & $\mathbf{- 1 0 , 1 9 \%}$ \\
\hline
\end{tabular}

Źródło: Komunikaty Zarządu Związku Kontroli Dystrybucji Prasy o wysokości nakładów i dystrybucji tytułów kontrolowanych przez ZKDP w 2010 i 2017 r.

7 Biblioteka Narodowa, Stan czytelnictwa w Polsce w 2017 roku, https://www.bn.org.pl/ aktualnosci/3497-stan-czytelnictwa-w-polsce---pelny-raport-do-pobrania.html (dostęp: 20.05.2019). 
Dane o sprzedaży pozostałych tygodników są deklaratywne i niemożliwe do zweryfikowania. W 2009 roku podano, że 99 tytułów wchodzących w skład Porozumienia Reklamowego Tygodnik Lokalny osiągnęło sprzedaż 704199 egzemplarzy i czytelnictwo ostatniego wydania na poziomie 2 mln osób 8 . Badania czytelnictwa 135 tygodników lokalnych zrealizowane w listopadzie 2014 i 2015 roku $^{9}$ wykazały, że czytelnikami ostatniego wydania były 3 mln osób. Wielkości sprzedaży nie ujawniono ${ }^{10}$.

Chociaż tygodniki lokalne mają na swoich rynkach ugruntowaną pozycję i stanowią ważne źródło informacji z danego regionu, to - zwłaszcza wśród młodych osób - przegrywają konkurencję z internetem ${ }^{11}$. Wydawcy lokalni podejmują wysiłki cyfryzacji swoich tytułów, ale do najpopularniejszych serwisów z informacjami lokalnymi należą te, które są firmowane przez dużych wydawców ogólnopolskich i horyzontalne portale internetowe ${ }^{12}$. Według informacji zgromadzonych przez Stowarzyszenie Gazet Lokalnych serwisy internetowe największych tygodników lokalnych miały po kilkadziesiąt tysięcy unikalnych użytkowników ${ }^{13}$, ale próby monetyzacji ich zainteresowania były mało skuteczne. Sprzedaż e-wydań czy pobieranie opłat za dostęp do treści umieszczanych $\mathrm{w}$ internecie nie pojawiały się $\mathrm{w}$ sprawozdaniach finansowych wydawców tygodników lokalnych jako osobne pozycje.

\section{Tygodniki lokalne na rynku reklamowym}

Wydatki na reklamę w prasie drukowanej (w dziennikach i czasopismach) maleją w Polsce od 2005 roku, kiedy to prawie co trzecia złotówka wydawana na reklamę trafiała do prasy ${ }^{14}$. Szacuje się, że w 2018 roku do wydawców prasy trafiała zaledwie co 12 złotówka wydawana na reklamę $e^{15}$.

8 Por. Nikt nie jest tak blisko spraw lokalnych, jak my, https://www.slideserve.com/cid/nikt-nie-jest-tak-blisko-spraw-lokalnych-jak-my (dostęp: 2.04.2019).

9 W 2018 r. SGL zrezygnowało z badań czytelnictwa prowadzonych przez spółkę PBC. Por. Sprawozdanie z działalności Rady Wydawców Stowarzyszenia Gazet Lokalnych za 2018 rok, http:// gazetylokalne.pl/sprawozdania-finansowe/ (dostęp: 12.07.2019).

10 Millward Brown, Badanie czytelnictwa gazet lokalnych. Opracowanie dla Biura Reklamy Gazet Lokalnych, styczeń 2016, http://www.reklamawprasie.pl/badania.html (dostęp: 12.07.2019).

11 Por. badania prowadzone w latach 2009 i 2011 przez Polskie Badania Internetu oraz raport Reuters Institute z 2018 r. The Digital Transition of Local News, http://www.digitalnewsreport.org/ publications/2018/digital-transition-local-news/ (dostęp: 12.07.2019).

12 Por. raport: PBI (Polskie Badania Internetu), Wiadomości lokalne w internecie. Zawartość i popularność serwisów, profil użytkowników, http://pbi.org.pl/wp-content/uploads/2016/12/02-RAPORT-Wiadomo\%C5\%9Bci-lokalne-2016.pdf (dostęp: 12.07.2019).

13 Por. Sprawozdanie z działalności Rady Wydawców Stowarzyszenia Gazet Lokalnych za 2017 rok, http://gazetylokalne.pl/wp-content/uploads/2018/05/Sprawozdanie_merytoryczne_2017_www_ gazetylokalne_pl.pdf (dostęp: 12.07.2019).

14 Por. Statistical Fact Book 2010, www.impactor.pl (dostęp: 17.05.2013).

15 Por. Raport Domu Mediowego Starcom za 2018 rok. 
Strukturalny spadek wpływów reklamowych dotknął również wydawców prasy lokalnej, choć przyjęło się uważać, że tytuły lokalne, w tym tygodniki lokalne, są mniej wrażliwe na dekoniunkturę na rynku reklamowym, bo posiadają stałą grupę reklamodawców. Należą do niej drobne firmy lokalne niemogące sobie pozwolić na reklamę w mediach o większym zasięgu, bądź nie mające takiej potrzeby ze względu na zakres swojego działania. Dysponując niewielkim budżetem reklamowym, firmy te nie korzystają z usług profesjonalnych agencji reklamowych i nie prowadzą precyzyjnych pomiarów efektywności zamieszczanych w lokalnych mediach ogłoszeń. Dla wielu z nich reklama w lokalnym piśmie ma zresztą bardziej wizerunkowy niż sprzedażowy cel.

Lokalny rynek reklamowy, choć względnie stabilny, jest bardzo płytki. Pojawienie się konkurencji (lokalnego dodatku w dzienniku regionalnym, pisma samorządowego itp.) lub nowego medium (lokalnej rozgłośni radiowej, serwisu internetowego itp.) uszczupla na ogół wpływy reklamowe tygodników lokalnych. Na spadek wpływów reklamowych wydawców lokalnych największy wpływ miało jednak uczynienie $\mathrm{z}$ wyszukiwarek internetowych platformy ogłoszeniowej dla małych producentów i usługodawców oraz rozwój funkcji marketingowej mediów społecznościowych.

Jak wynika z najnowszych badań, już 85\% mikroprzedsiębiorstw i małych firm promuje się w internecie za pomocą własnej strony, $75 \%$ prowadzi fanpage na Facebooku, a 64\% wydaje dodatkowo pieniądze na reklamę internetową (w mediach społecznościowych, pozycjonowanie w wyszukiwarce internetowej, banery na różnych stronach internetowych ${ }^{16}$.

Wydawcy tygodników lokalnych przyczyn spadku przychodów z reklamy doszukują się zarówno w zmniejszeniu wydatków reklamowych w prasie drukowanej, jak i w agresywnej konkurencji ze strony innych tytułów lokalnych ${ }^{17}$.

\section{Metodologia badania kondycji finansowej wydawców tygodników lokalnych}

Wydawcy tygodników lokalnych to grupa bardzo zróżnicowana pod względem organizacyjnym, prawnym i ekonomicznym. Należą do niej spółki z ograniczoną odpowiedzialnością, spółki jawne, spółdzielnie dziennikarskie, osoby prowadzące indywidualną działalność gospodarczą. Część z nich skupia się wyłącznie na działalności medialnej (wydawanie gazet i czasopism, prowadzenie serwisu

16 Badania na zlecenie ING Banku Śląskiego przeprowadzone w kwietniu 2019 r. Zob. ING Bank Śląski, Jak reklamują się małe firmy?, https://media.ingbank.pl/informacje-prasowe/926/pr/439597/ ing-jak-reklamuja-sie-male-firmy (dostęp: 12.07.2019).

17 Por. Sprawozdanie z działalności Rady Wydawców Stowarzyszenia Gazet Lokalnych za 2018 rok, http://gazetylokalne.pl/wp-content/uploads/2015/10/Sprawozdanie_z_dzia\%C5\%82alnosci_ RadyWydawc\%C3\%B3w_SGLw-roku2018.pdf (dostęp: 12.07.2019). 
internetowego), część podejmuje dodatkowe rodzaje działalności (wynajem pomieszczeń, handel czy też np. „usługi z zakresu stolarki budowlanej i obróbki mechanicznej elementów metalowych" ${ }^{18}$ ). Przychody z działalności takich podmiotów różnią się znacznie i wynoszą od kilkuset tysięcy do kilku milionów złotych rocznie.

W analizie wykorzystano sprawozdania finansowe wydawców tygodników lokalnych za lata 2010-2018 składane do Krajowego Rejestru Sądowego (KRS). Ramy czasowe wyznaczają: rok, w którym odnotowano najwyższe nakłady i sprzedaż prasy w Polsce ${ }^{19}$, oraz wymóg zachowania jak największej aktualności.

Dobór próby badanej podlegał licznym ograniczeniom, do których należały:

1. Forma prawna prowadzonej działalności - nie wszystkie podmioty prowadzące działalność wydawniczą są zobowiązane do raportowania wyników swojej działalności ${ }^{20}$.

2. Względy techniczne i finansowe - bezpłatny dostęp przez internet do pełnych danych o podmiotach z KRS oraz do składanych przez nich dokumentów finansowych jest możliwy dopiero od 15 marca 2018 roku. Elektroniczne repozytorium dokumentów finansowych zawiera wyłącznie dokumenty składane od tej daty, pod warunkiem że podmiot wywiązał się ze swoich obowiązków sprawozdawczych wobec KRS. Sprawozdania finansowe $\mathrm{z}$ lat wcześniejszych dostępne są $\mathrm{w}$ sądach rejestrowych (można je przeglądać w czytelni sądu rejonowego właściwego dla siedziby wpisanego do rejestru przedsiębiorcy) lub dokonać ich zakupu w wywiadowni gospodarczejej ${ }^{21}$.

3. Niekompletność pozyskanych danych finansowych - wiele podmiotów gospodarczych posiada zaległości lub braki w składaniu sprawozdań finansowych.

$\mathrm{W}$ rezultacie analizie poddano sprawozdania finansowe 23 wydawców $\mathrm{z}$ lat 2010-2018. Uzyskane dane o przychodach ze sprzedaży, kosztach prowadzonej działalności, ze szczególnym uwzględnieniem wydatków na wynagrodzenia, oraz o wyniku finansowym w poszczególnych latach pozwoliły na prześledzenie zmian w sytuacji finansowej statystycznego (uśrednionego) wydawcy w poszczególnych grupach dochodowych. Wydawców, ze względu na zróżnicowanie przychodów, podzielono bowiem na trzy grupy:

1. mali (7 podmiotów) - wydawcy, którzy w 2010 roku osiągali do $1 \mathrm{mln}$ zł przychodu ze sprzedaży;

18 Rodzaj dodatkowej działalności w sprawozdaniu finansowym jednego z wydawców.

19 Z przeprowadzonych przez autorkę badań w roku 2010 osiągnięto najwyższy poziom nakładu jednorazowego czasopism. Por. J. Dzierżyńska-Mielczarek, Rynek mediów w Polsce. Zmiany pod wplywem nowych technologii cyfrowych, Oficyna Wydawnicza ASPRA-JR, Warszawa 2018.

20 Katalog podmiotów zobowiązanych do rejestracji znajduje się w art. 36 Ustawy o Krajowym Rejestrze Sądowym (Dz.U. 1997, nr 121, poz. 769). Nie podlegają mu np. osoby prowadzące działalność gospodarczą i spółki cywilne.

21 Koszty dostępu do sprawozdań finansowych wydawców tygodników lokalnych wykorzystanych w niniejszej analizie zostały pokryte przez Stowarzyszenie Dziennikarzy i Wydawców REPROPOL. 
2. średni (9 podmiotów) - wydawcy, którzy w 2010 roku osiągali 1-3 mln zł przychodu ze sprzedaży;

3. duzi (7 podmiotów) - wydawcy, którzy w 2010 roku osiągali ponad $3 \mathrm{mln}$ zł przychodu ze sprzedaży.

Uzasadnieniem takiego podziału, poza skalą działalności prasowej, były również wielkość i rodzaj zatrudnienia w redakcjach tygodników. Wydatki na wynagrodzenia, stanowiące podstawowy składnik kosztów wydawnictwa prasowego, w dużej mierze decydowały o rentowności przedsiębiorstwa, ale też o możliwościach jego rozwoju. Zatrudnienie u dużych wydawców przekraczało na ogół 20 osób, wśród których oprócz dziennikarzy znajdowali się operatorzy sprzętu komputerowego, pracownicy działów reklamy, administracji, kolportażu itd. Mali wydawcy unikali zazwyczaj zatrudnienia etatowego, spłaszczając struktury redakcyjne, stawiając na wielofunkcyjność pracowników, w tym łączenie obowiązków dziennikarskich z akwizycją reklam czy organizowaniem kolportażu.

System kolportażu był kolejną cechą różniącą wydawców. Duzi wydawcy - rozszerzając zasięg wydawanych przez siebie tytułów na kilka sąsiednich powiatów - korzystali z profesjonalnego kolportażu (Ruch, Kolporter itp.) i systemu prenumeraty (Poczta Polska, prenumerata redakcyjna). Mali wydawcy, ograniczając zasięg swoich tytułów do jednego powiatu, organizowali zazwyczaj własny system kolportażu.

Kolejną cechą dywersyfikującą był sposób funkcjonowania w internecie. Duzi wydawcy, oprócz rozbudowanych serwisów informacyjnych online, prowadzili sprzedaży e-wydań swoich tygodników oraz podejmowali próby wprowadzenia płatnego dostępu do produkowanych przez siebie treści. Mali wydawcy nie decydowali się na monetyzację kontentu i wykorzystywali witryny internetowe swoich tytułów do poszerzenia zasięgu wśród czytelników i reklamodawców.

\section{Przychody i koszty działalności wydawniczej tygodników lokalnych}

Na przychody z działalności wydawniczej składają się głównie środki ze sprzedaży egzemplarzowej oraz wpływy z reklam i ogłoszeń ${ }^{22}$. Mimo różnic w sytuacji finansowej poszczególnych wydawców tygodników lokalnych, przychody z działalności wydawniczej od 2010 roku zmniejszyły się o około 1/3 (por. tabela 2).

Nie wszyscy wydawcy ujawniają wysokość przychodów w rozbiciu na oba źródła, dlatego w pewnym przybliżeniu można ocenić, że wpływy reklamowe stanowią od $50 \%$ do $70 \%$ przychodów ze sprzedaży. W przypadku małych wydawców przychody reklamowe spadają szybciej niż przychody ze sprzedaży egzemplarzowej, a tym samym wysokość wpływów z obu źródeł wyrównuje się. U dużych wydawców sytuacja jest odwrotna. Dynamika spadku przychodów ze sprzedaży gazet (mimo podwyżek ceny egzemplarzowej) jest większa niż przychodów z reklamy.

$22 \mathrm{~W}$ analizie pominięto tzw. inne przychody. 
Tabela 2. Uśrednione wyniki finansowe wydawców w 2018 r. w stosunku do 2010, 2012 lub 2014 r. (w mln zł)

\begin{tabular}{|l|r|r|r|r|r|r|r|r|r|}
\hline & \multicolumn{2}{|c|}{ Duzi wydawcy } & \multicolumn{2}{c|}{ Sredni wydawcy } & \multicolumn{3}{c|}{ Mali wydawcy } \\
\hline & $\mathbf{2 0 1 0}$ & $\mathbf{2 0 1 8}$ & $\begin{array}{r}\text { Wzrost/ } \\
\text { spadek }\end{array}$ & $\mathbf{2 0 1 4}$ & $\mathbf{2 0 1 8}$ & $\begin{array}{l}\text { Wzrost/ } \\
\text { spadek }\end{array}$ & $\mathbf{2 0 1 2}$ & $\mathbf{2 0 1 8}$ & $\begin{array}{c}\text { Wzrost/ } \\
\text { spadek }\end{array}$ \\
\hline Przychody & 4,82 & 3,19 & $-33 \%$ & 1,41 & 0,86 & $-39 \%$ & 0,73 & 0,57 & $-22 \%$ \\
\hline Koszty & 3,61 & 2,85 & $-21 \%$ & 1,37 & 0,93 & $-32 \%$ & 0,70 & 0,62 & $-12 \%$ \\
\hline $\begin{array}{l}\text { W tym } \\
\text { wynagrodzenia }\end{array}$ & 1,56 & 1,56 & $0 \%$ & 0,63 & 0,41 & $-35 \%$ & 0,30 & 0,31 & $+5 \%$ \\
\hline Zysk/strata & 1,21 & 0,34 & $-72 \%$ & 0,16 & $-0,07$ & $-148 \%$ & 0,03 & $-0,05$ & $-254 \%$ \\
\hline
\end{tabular}

Źródło: opracowanie własne.

Najwyższy spadek przychodów (o prawie 40\%) odnotowali średni wydawcy, którzy już w 2014 roku (i w latach wcześniejszych) balansowali na granicy opłacalności lub ponosili straty z działalności wydawniczej (por. tabela 2). Ich model biznesowy sprowadzał się do ograniczenia kosztów, w tym na wynagrodzenia, co musiało przełożyć się na jakość oferowanego produktu (por. wykres 1). Brak inwestycji (np. w internet) i działań promocyjno-marketingowych nakręcał negatywnie spiralę nakładu (mniejsza sprzedaż egzemplarzowa to mniejsze wpływy reklamowe, a tym samym mniej środków na działalność redakcyjną i inwestycje, co skutkuje zmniejszeniem sprzedaży itd.).

Wykres 1. Uśrednione wyniki finansowe średnich wydawców w latach 2014 i 2018 (w tys. zł)

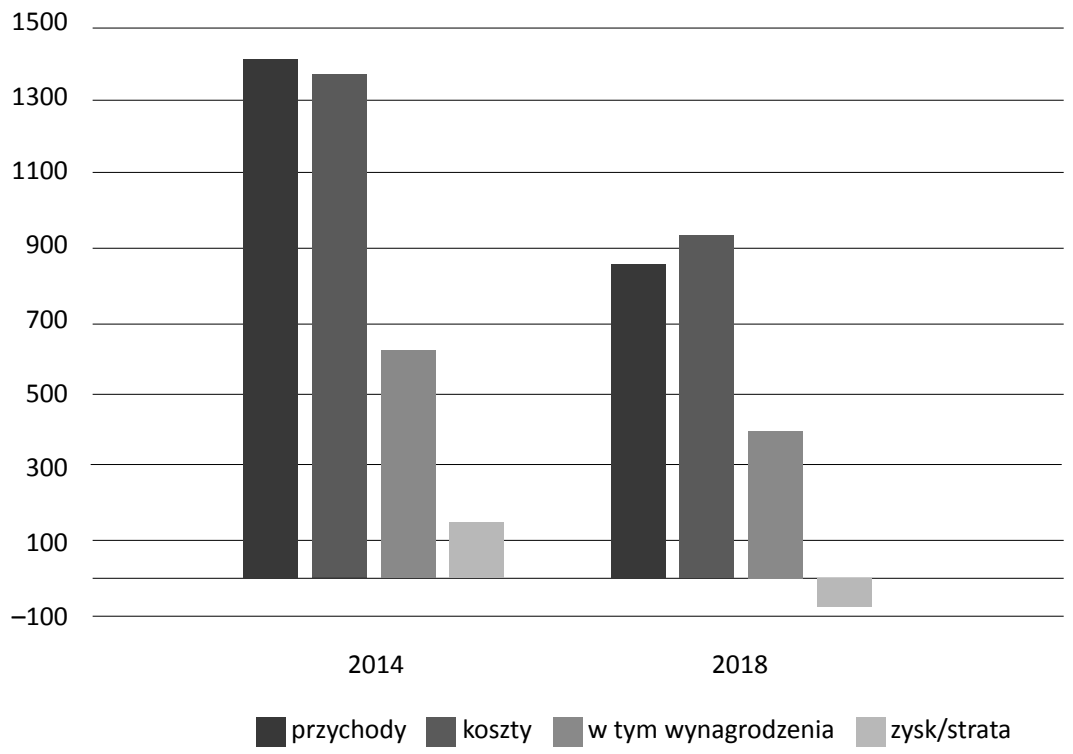

Źródło: opracowanie własne. 
W najmniejszym stopniu spadek przychodów dotknął małych wydawców, którzy działając w mikroskali (często na obszarze mniejszym od powiatu), mają ugruntowaną pozycję na rynku czytelniczym i reklamowym. Nawet monopolistyczna pozycja nie zapewnia im jednak dodatniego wyniku finansowego (por. tabela 2 i wykres 2). Ich działalność można uznać prawie za hobbystyczną, bo straty wynikające $\mathrm{z}$ wydawania tygodnika są $\mathrm{w}$ ich przypadku najwyższe i muszą być pokrywane z innych źródeł.

Wykres 2. Uśrednione wyniki finansowe małych wydawców w latach 2012 i 2018 (w tys. zł)

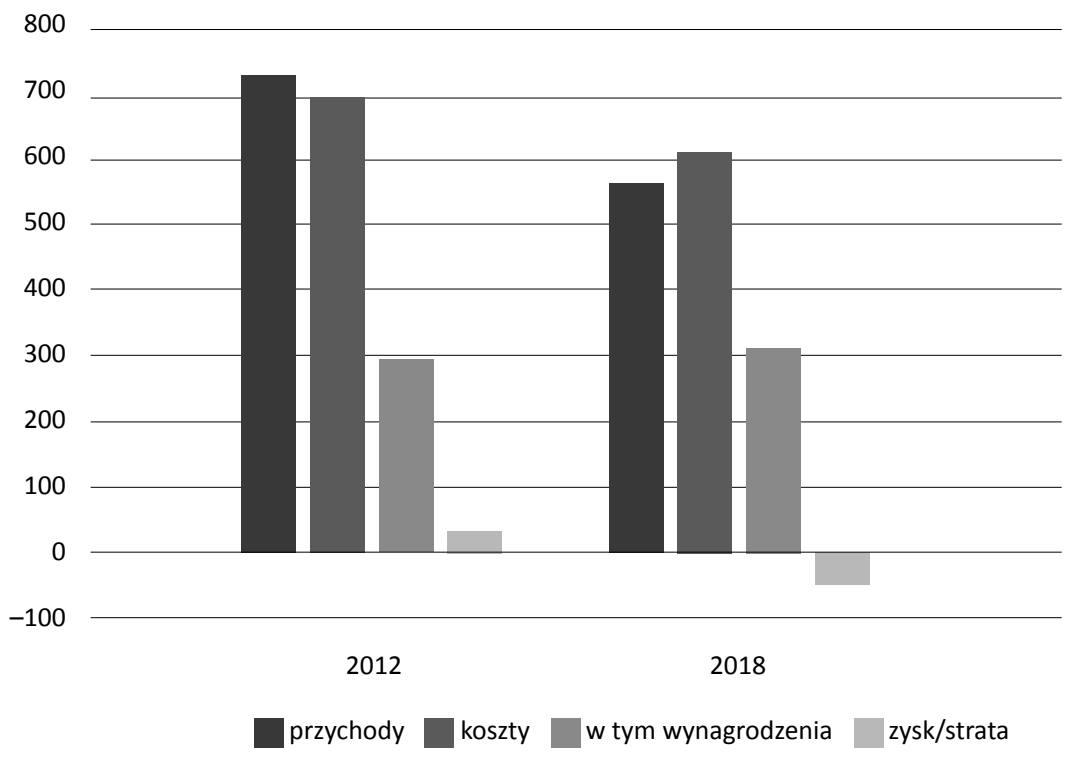

Źródło: opracowanie własne.

Wszyscy wydawcy tygodników lokalnych zmuszeni zostali w ostatnich latach do ograniczenia kosztów. Ich zmniejszenie to w dużej części efekt spadku sprzedaży egzemplarzowej, a tym samym kosztów druku i kolportażu. U największych i najmniejszych wydawców cięcia wydatków nie dotyczyły wynagrodzeń (por. tabela 2 oraz wykresy 2 i 3). W przypadku pierwszych spowodowane to było zapewne koniecznością zwiększenia zatrudnienia w działach online redakcji, bo wszystkie tytuły rozwijały własne serwisy internetowe oraz e-wydania. Małym wydawcom trudno było oszczędzać na wynagrodzeniach, bo otrzymywali je wyłącznie pracownicy niezbędni do funkcjonowania tytułu.

Trudną sytuację rynkową wydawców tygodników lokalnych najlepiej obrazuje pogorszenie osiąganych wyników finansowych. Zyski dużych wydawców zmniejszyły się w latach 2010-2018 o ponad 70\%. Pozostali wydawcy odnotowali straty. Tylko w latach 2014-2018 statystyczny średni wydawca pogorszył wynik finansowy o prawie $150 \%$. W katastrofalnej sytuacji znaleźli się mali wydawcy. Statystycznie 
Wykres 3. Uśrednione wyniki finansowe dużych wydawców w latach 2012 i 2018 (w tys. zł)

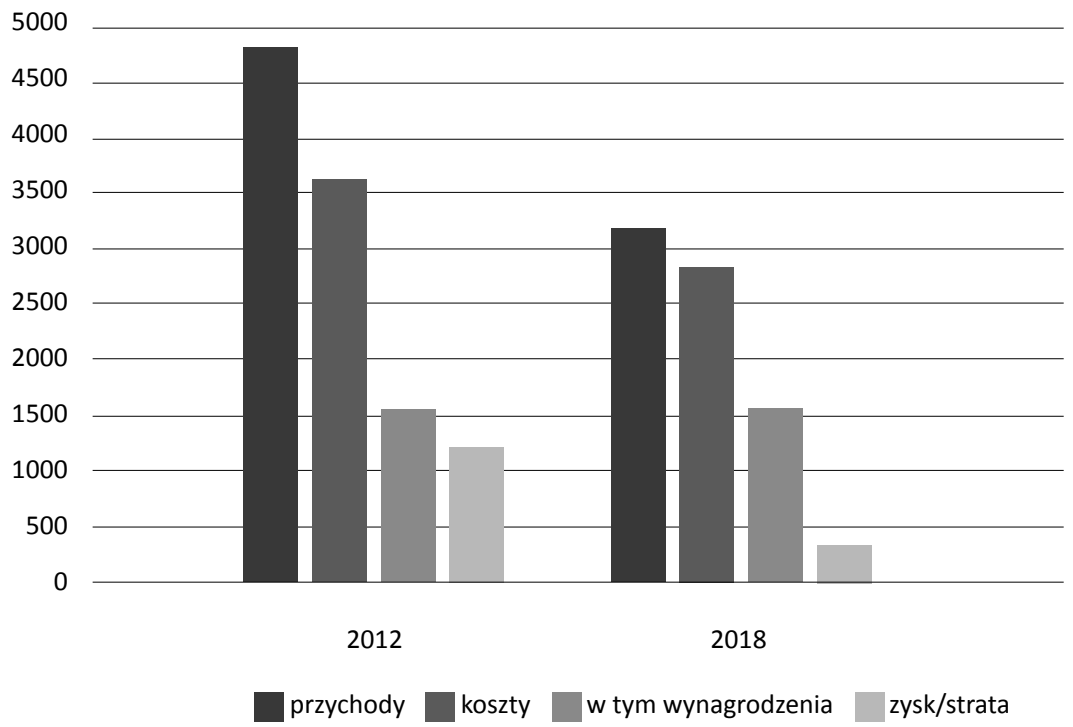

Źródło: opracowanie własne.

Wykres 4. Rentowność sprzedaży wydawców (w \%)

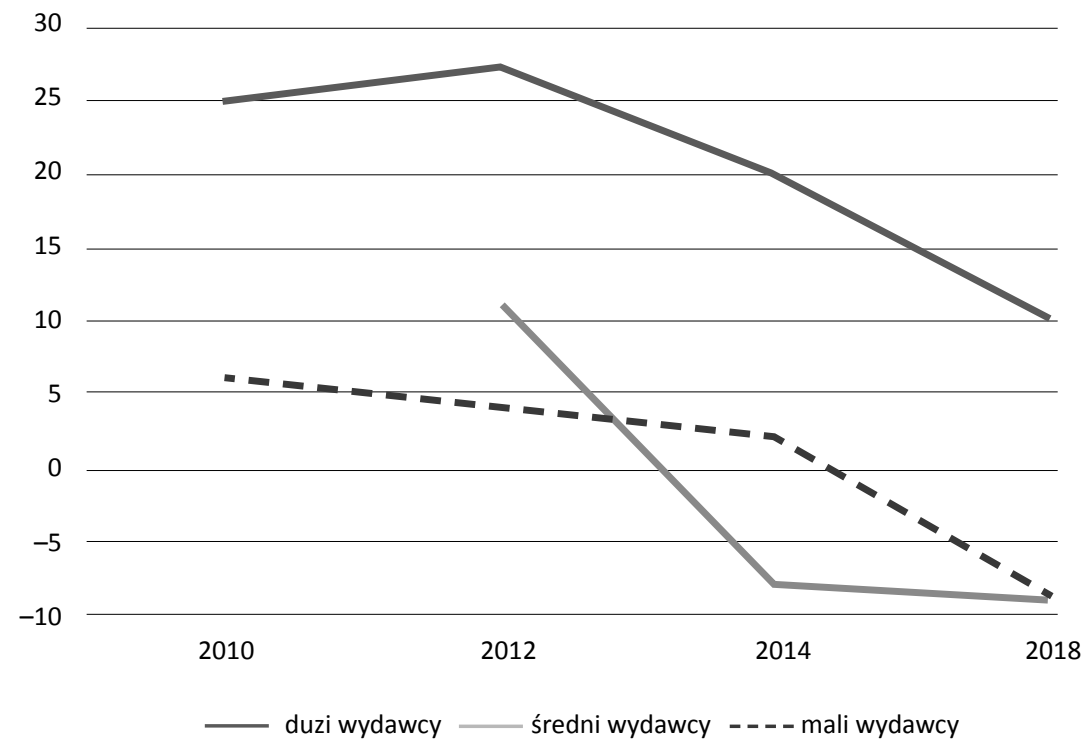

Źródło: opracowanie własne. 
każdy z nich niewielki zysk w 2012 roku zamienił na dwuipółkrotnie większą stratę w 2018 roku (por. tabela 2 oraz wykresy 1-3).

Jak bardzo opłacalne było, jeszcze kilka lat temu, wydawanie dużego tygodnika lokalnego, pokazuje przykład jednego z wydawców. Jego rentowność sprzedaży $\left(\right.$ ROS $^{23}$ ) w 2010 roku wynosiła 23\%. W 2018 roku zmalała do 6\%, czyli prawie czterokrotnie. Uśrednione spadki sprzedaży obrazuje wykres 4 . Rentowność sprzedaży statystycznego dużego wydawcy wynosiła w 2010 roku 25\%, a w 2018 roku dwuipółkrotnie mniej, czyli 10\%. Rentowność sprzedaży średniej wielkości wydawców z poziomu 11\% w 2012 roku spadła w 2018 roku poniżej zera do $-9 \%$. Na jednej złotówce sprzedaży zrealizowanej w 2010 roku statystyczny mały wydawca zarabiał 6 groszy (6\%), w 2018 roku tracił 9 groszy $(-9 \%)$.

\section{Podsumowanie}

Kondycja finansowa wydawców tygodników lokalnych znacznie się w kilku ostatnich latach pogorszyła. Zmalały ich przychody ze sprzedaży egzemplarzowej i wpływy reklamowe. Jeszcze w 2012 roku najwięksi wydawcy odnotowali wzrost rentowności sprzedaży i z optymizmem patrzyli w przyszłość ${ }^{24}$. Właściciele mniejszych tytułów mimo pogorszenia wskaźników finansowych osiągali zyski i nie musieli gwałtownie redukować kosztów.

Zmniejszenie czytelnictwa prasy drukowanej, a zwłaszcza odpływ czytelników i reklamodawców do internetu, choć w lokalnej prasie nastąpiły z opóźnieniem, odbiły się negatywnie na przychodach wydawców. Średnio spadły one o $1 / 3$, choć najwięcej (prawie 40\%) stracili średni wydawcy, których przychody w 2010 roku wynosiły 1-3 mln zł. Ich pozycja na lokalnym rynku czytelniczym i reklamowym nie była na tyle ustabilizowana, żeby utrzymać status quo, a posiadane zasoby finansowe zbyt małe, by podjąć skuteczną walkę w internecie. Dokonali oni największej redukcji kosztów, w tym wydatków na wynagrodzenia, co mogło się przełożyć na jakość oferowanego produktu i przyspieszyło odpływ czytelników i reklamodawców. W efekcie działalność wydawnicza zaczęła przynosić im straty.

Duzi wydawcy, z przychodami rocznymi w 2010 roku powyżej $3 \mathrm{mln}$ zł, mimo spadku wpływów ze sprzedaży egzemplarzowej i reklamy średnio o 1/3, ograniczyli się do oszczędności wynikających ze spadku kosztów druku i kolportażu. Nie dokonali redukcji wydatków na wynagrodzenia, co może świadczyć o dbałości o jakość tytułu w druku lub rozbudowę jego obecności w internecie. Taka polityka uchroniła ich przed stratami, ale ograniczyła osiągane zyski o ponad $70 \%$.

23 ROS (return of sale) - wskaźnik określający, ile zysku netto przypada na jedną złotówkę zrealizowanej sprzedaży. Obliczany jest jako iloraz zysku netto wypracowanego przez przedsiębiorstwo i wartości osiągniętego przychodu ze sprzedaży.

24 Por. publikację w „Rzeczpospolitej” z 2012 r., w której podano, że wbrew trendom ogólnopolskim nakłady tygodników lokalnych nie spadają, wciąż powstają nowe tytuły, a ich wydawcy osiągają zyski. I. Janke, Potęga prasy lokalnej, „Rzeczpospolita”, 3.03.2012. 
Mali wydawcy, dla których działalność wydawnicza już w 2010 roku nie była źródłem wysokich zysków, najsilniej odczuli dekoniunkturę na rynku prasy drukowanej. Wprawdzie ich przychody sprzedażowe i reklamowe spadły od 2012 roku średnio tylko o 1/5, to brak możliwości ograniczenia, i tak niskich, kosztów działalności wydawniczej, naraził ich na największe straty.

Spadek rentowności wszystkich wydawców tygodników lokalnych oznacza dla jednych koniec inwestycji i ograniczenie możliwości rozwoju, dla innych konieczność rezygnacji z - przynoszącej straty - działalności wydawniczej. Nieopłacalność dotychczasowych modeli biznesowych sprzyjać będzie zjawiskom dalszej koncentracji własności, bo tylko w ramach dużej grupy medialnej można jeszcze obniżyć niektóre koszty (np. administracyjne, dotyczące produkcji treści). Większe organizacje medialne mogą też pozwolić sobie na inwestycje w skuteczne metody monetyzacji produkowanych treści czy zarabianie na reklamie w sieci.

Ograniczenie ekonomicznej samowystarczalności sprzyjać też będzie większej komercjalizacji lokalnej prasy. Już teraz wiele tytułów publikuje wszelkie opłacalne informacje i dodatki umożliwiające pozyskanie reklamodawców. Dalsza merkantylizacja tygodników lokalnych pozbawi je funkcji kontrolnej wobec władz samorządowych i różnych grup interesu w regionie.

Pogarszająca się kondycja finansowa wydawców nie pozostanie bez wpływu na jakość lokalnej prasy, zwłaszcza jej redakcyjną zawartość. Niższe niż w przypadku innych mediów zarobki nie przyciągną do niej dobrych dziennikarzy, zwłaszcza jeśli nie oferują stałej, stabilnej pracy.

Można przypuszczać, że na rynku medialnym pojawiać się będzie coraz więcej ogłoszeń typu:

Sprzedam dwie działające i znane na rynku lokalnym gazety z dochodem średnim rocznym ok. 100-120 tys. zł. Ponadto w pakiecie mocny fanpage z 6000 aktywnych użytkowników, budowany przez lata i baza klientów. Pracowników brak, bo dziennikarze pracują na umowę zlecenie albo wystawiają faktury. Zainteresowanych zapraszam do kontaktu ${ }^{25}$.

\section{Bibliografia}

Biblioteka Narodowa, Stan czytelnictwa w Polsce w 2017 roku, https://www.bn.org.pl/ aktualnosci/3497-stan-czytelnictwa-w-polsce---pelny-raport-do-pobrania.html (dostęp: 20.05.2019).

Biznes oferty, https://www.biznesoferty.pl/idoferty,115819.html (dostęp: 2.04.2019).

Dzienniki regionalne w Polsce. Stan na koniec grudnia 2013 roku, red. nauk. P. Kuca, W. Furman, K. Wolny-Zmorzyński, Wydawnictwo Uniwersytetu Rzeszowskiego, Rzeszów 2014.

Dzierżyńska-Mielczarek J., Rynek mediów w Polsce. Zmiany pod wpływem nowych technologii cyfrowych, Oficyna Wydawnicza ASPRA-JR, Warszawa 2018.

25 Ogłoszenie zamieszczone na https://www.biznesoferty.pl/idoferty,115819.html (dostęp: 2.04.2019). 
Gierula M., Polska prasa lokalna 1989-2000. Typologia i społeczne funkcjonowanie, Wydawnictwo Uniwersytetu Śląskiego, Katowice 2005.

ING Bank Śląski, Jak reklamuja się małe firmy?, https://media.ingbank.pl/informacje-prasowe/926/pr/439597/ing-jak-reklamuja-sie-male-firmy (dostęp: 12.07.2019).

Jachimowski M., Regiony periodycznej komunikacji medialnej. Studium prasoznawczo-politologiczne o demokratyzacji komunikacji medialnej, Wydawnictwo Uniwersytetu Śląskiego, Katowice 2006.

Janke I., Potega prasy lokalnej, „Rzeczpospolita”, 3.03.2012.

Jaruga-Wosik E., Strukturalne i jakościowe przemiany w mediach lokalnych, „Polityczne Studia Środkowoeuropejskie" 2016, nr 4, s. 125-144.

Kępa-Mętrak J., Prasa samorządowa $w$ polskim systemie medialnym, Wydawnictwo Uniwersytetu Jana Kochanowskiego, Kieleckie Towarzystwo Naukowe, Kielce 2015.

Kowalczyk R., Media lokalne w Polsce, t. 1-3, Wydawnictwo „Contact”, Poznań 2008.

Media lokalne w Szczecinie, Raport $z$ badań mediów lokalnych w Szczecinie $w 2010$ roku, red. J. Kania, R. Cieślak, Wydawnictwo Naukowe Uniwersytetu Szczecińskiego, Szczecin 2011.

Michalczyk S., Media lokalne w systemie komunikowania. Współczesne tendencje i uwarunkowania rozwojowe, Wydawnictwo Uniwersytetu Śląskiego, Katowice 2000.

Millward Brown, Badanie czytelnictwa gazet lokalnych. Opracowanie dla Biura Reklamy Gazet Lokalnych, styczeń 2016, http://www.reklamawprasie.pl/badania.html (dostęp: 12.07.2019).

Nikt nie jest tak blisko spraw lokalnych, jak my, https://www.slideserve.com/cid/nikt-nie-jest-tak-blisko-spraw-lokalnych-jak-my (dostęp: 2.04.2019).

PBI (Polskie Badania Internetu), Wiadomości lokalne w internecie. Zawartość i popularność serwisów, profil użytkowników, http://pbi.org.pl/wp-content/uploads/2016/12/02-RAPORT-Wiadomo\%C5\%9Bci-lokalne-2016.pdf (dostęp: 12.07.2019).

Pokrzycka L., Prasa ogólnoinformacyjna w regionie lubelskim po 1989 r., Wydawnictwo Uniwersytetu Marii Curie-Skłodowskiej, Lublin 2009.

Publiczna telewizja regionalna $w$ Polsce. Stan na koniec grudnia 2015 roku, red. nauk. P. Kuca, W. Furman, K. Wolny-Zmorzyński, Wydawnictwo Uniwersytetu Rzeszowskiego, Rzeszów 2018.

Radio regionalne $w$ Polsce. Stan na koniec grudnia 2014 roku, red. nauk. P. Kuca, W. Furman, K. Wolny-Zmorzyński, Wydawnictwo Uniwersytetu Rzeszowskiego, Rzeszów 2016.

Raport Domu Mediowego Starcom za 2018 rok.

Reuters Institute, The Digital Transition of Local News, http://www.digitalnewsreport.org/publications/2018/digital-transition-local-news/ (dostęp: 2.04.2019).

Sprawozdanie z działalności Rady Wydawców Stowarzyszenia Gazet Lokalnych za 2017 rok, http://gazetylokalne.pl/sprawozdania-finansowe/ (dostęp: 12.07.2019).

Sprawozdanie z działalności Rady Wydawców Stowarzyszenia Gazet Lokalnych za 2018 rok, http://gazetylokalne.pl/sprawozdania-finansowe/ (dostęp: 12.07.2019).

Statistical Fact Book 2010, www.impactor.pl (dostęp: 17.05. 2013).

Szostok P., Rajczyk R., Komunikowanie lokalne w Polsce. O instrumentach polityki komunikacyjnej samorząów, Gnome - Wydawnictwa Naukowe i Artystyczne, Katowice 2013.

Szot L., Koncentracja kapitału na polskim rynku prasowym. Studium przypadku, „Studia Medioznawcze" 2017, nr 2, s. 111-123.

Szynol A., Czy Polsce wciąż potrzebna jest regionalna prasa codzienna?, „Zeszyty Prasoznawcze" 2017, nr 3, s. 468-493.

Szynol A., Prasa codzienna na Dolnym Śląsku 1989-2003, Wydawnictwo Naukowe Dolnośląskiej Szkoły Wyższej Edukacji TWP, Wrocław 2004.

Ustawa z dnia 20 sierpnia 1997 r. o Krajowym Rejestrze Sądowym, Dz.U. 1997, nr 121, poz. 769.

Ustawa z dnia 7 listopada 1996 r. o obowiązkowych egzemplarzach bibliotecznych, Dz.U. 1996, nr 152, poz. 722 .

ZKDP, Komunikaty Zarządu Związku Kontroli Dystrybucji Prasy o wysokości nakładów i dystrybucji tytułów kontrolowanych przez ZKDP w 2010 i 2017 r. 